\title{
Chemotherapy-based versus chemotherapy-free stem cell mobilization ( \pm plerixafor) in multiple myeloma patients: an Italian cost-effectiveness analysis
}

\author{
Carlo Lazzaro $\mathbb{D}^{1} \cdot$ Luca Castagna ${ }^{2}$ - Francesco Lanza $\mathbb{D}^{3} \cdot$ Daniele Laszlo $\mathbb{C}^{4} \cdot$ Giuseppe Milone $\mathbb{C}^{5} \cdot$ Luca Pierelli $^{6}$. \\ Riccardo Saccardi ${ }^{7}$
}

Received: 27 May 2020 / Revised: 3 February 2021 / Accepted: 18 February 2021 / Published online: 22 March 2021

(c) The Author(s) 2021. This article is published with open access

\begin{abstract}
Given the availability and efficacy of the mobilizing agent plerixafor in augmenting hematopoietic progenitor cell mobilization with granulocyte colony-stimulating factor (G-CSF), there is a strong case for comparing the cost-effectiveness of mobilization with G-CSF + cyclophosphamide versus G-CSF alone. This study investigated the cost and effectiveness (i.e., successful 4 million-CD34 ${ }^{+}$collection) of G-CSF alone versus high-dose cyclophosphamide $\left(4 \mathrm{~g} / \mathrm{m}^{2}\right)+$ G-CSF mobilization ( \pm on-demand plerixafor) in patients with multiple myeloma (MM) eligible for autograft in Italy. A decision tree-supported cost-effectiveness analysis (CEA) model in MM patients was developed from the societal perspective. The CEA model compared G-CSF alone with cyclophosphamide $4 \mathrm{~g} / \mathrm{m}^{2}+\mathrm{G}-\mathrm{CSF}$ ( \pm on-demand plerixafor) and was populated with demographic, healthcare and non-healthcare resource utilization data collected from a questionnaire administered to six Italian oncohematologists. Costs were expressed in Euro (€) 2019. The CEA model showed that G-CSF alone was strongly dominant versus cyclophosphamide + G-CSF ( \pm on-demand plerixafor), with incremental savings of $€ 1198.59$ and an incremental probability of a successful 4 million-CD34 ${ }^{+}$apheresis $(+0.052)$. Sensitivity analyses confirmed the robustness of the base-case results. In conclusion, chemotherapy-free mobilization ( \pm on-demand plerixafor) is a "good value for money" option for MM patients eligible for autograft.
\end{abstract}

\section{Introduction}

In patients with multiple myeloma (MM) eligible for autologous stem cell (SC) transplant (SCT), SC are mobilized in peripheral blood for subsequent collection using

These authors contributed equally: Luca Castagna, Francesco Lanza, Daniele Laszlo, Giuseppe Milone, Luca Pierelli, Riccardo Saccardi.

Supplementary information The online version contains supplementary material available at https://doi.org/10.1038/s41409021-01251-8.

Carlo Lazzaro

carlo.lazzaro@tiscalinet.it

1 Health Economist and Research Director, Studio di Economia Sanitaria, Milan, Italy

2 Oncology and Haematology Unit, BMT section, Istituto Clinico Humanitas, Rozzano, Italy

3 Hematology Section, Romagna Transplant Network, University Hospital "Santa Maria delle Croci", Ravenna, Italy granulocyte colony-stimulating factor (G-CSF) alone [1] or following chemotherapy with cyclophosphamide [1-4]. While various cyclophosphamide-based mobilization strategies are reported to mobilize $\mathrm{SC}$ while reducing toxicity [3] and improve SC yield, and prospective studies have used cyclophosphamide $1.0-7.0 \mathrm{~g} / \mathrm{m}^{2}+\mathrm{G}-\mathrm{CSF}$ to mobilize SC in MM patients [2, 5-7], curative effects in MM have not been proven [8-10].

Plerixafor in combination with G-CSF has shown superiority in SC mobilization compared with G-CSF alone, mobilizing sufficient $\mathrm{CD} 34^{+}$cells to support SCT in MM

4 Stem Cell Mobilization and Collection Unit, IEO IRCCS, Milan, Italy

5 Hematology and BMT Unit, Azienda Policlinico Vittorio Emanuele, Catania, Italy

6 Department of Experimental Medicine, University "Sapienza", Rome, Immune-hematology and Transfusion Medicine Unit, Azienda Ospedaliera San Camillo, Rome, Italy

7 Department of Cellular Therapy and Transfusion Medicine, Careggi University Hospital, Florence, Italy 
patients [11-16]. Given the availability of plerixafor to augment SC mobilization with G-CSF, there is a strong case for comparing the cost-effectiveness of mobilization with G-CSF + high dose $\left(4 \mathrm{~g} / \mathrm{m}^{2}\right)$ cyclophosphamide versus GCSF alone [17-23]. This study compared the costeffectiveness of chemotherapy-free and chemotherapybased mobilization ( \pm on-demand plerixafor) in MM patients eligible for autologous SCT at Italian oncohematology units.

\section{Methods}

\section{Decision model}

The opinions of a sample of convenience [24] of six Italian oncohematologists were elicited using a dedicated questionnaire to identify and quantify the parameters that were used for the cost-effectiveness analysis (CEA) model (Tables S1-S13) [25, 26].

Following the same approach as a previous CEA model of plerixafor in MM [23], the costs and probability of a successful 4 million-CD34 ${ }^{+}$collection in MM patients eligible for autologous SCT were calculated for SC mobilization with G-CSF alone versus cyclophosphamide $4 \mathrm{~g} / \mathrm{m}^{2}$ + G-CSF ( \pm on-demand plerixafor) using a decision tree model $[27,28]$. As per the oncohematologists' opinion, the time period for the decision tree ranged from SC mobilization to successful apheresis. Costs and outcomes of the subsequent autologous SCT were not included.

Since patients on cyclophosphamide show a higher risk of febrile neutropenia and/or need for red blood cell (RBC) and/or platelet (PLT) transfusions [27], the probability of these events, as well as achievement of successful apheresis, were estimated (Figures S1 and S2). The risk of death between mobilization and apheresis was not calculated.

\section{Probability of a successful CD34 ${ }^{+}$apheresis}

The probability of successful apheresis ( \pm on-demand plerixafor) was determined using both the oncohematologists' opinion and the results of a previous Italian CEA of plerixafor in chemotherapy-based mobilization in MM [22]. The oncohematologists estimated the probability of administering on-demand plerixafor in chemotherapy-free mobilization was $47 \%$ to make it as effective as chemotherapy-based mobilization. Since the probability of a successful 4 million-CD34 ${ }^{+}$apheresis was $83.8 \%$ with ondemand plerixafor versus $70.2 \%$ without plerixafor in the previous CEA [22], the average probability of achieving the effectiveness outcome for chemotherapy-free mobilization ( \pm on-demand plerixafor) was calculated as follows:

$$
[(47 \% \times 83.8 \%)+([1-47 \%] \times 70.2 \%)]=76.5 \%
$$

As the oncohematologists agreed that the probability of including plerixafor in cyclophosphamide + G-CSF mobilization was $9 \%$, the average probability of a successful apheresis following chemotherapy-based mobilization ( \pm on-demand plerixafor) was calculated as follows:

$$
[(9 \% \times 83.8 \%)+([1-9 \%] \times 70.2 \%)]=71.4 \%
$$

\section{Resource identification, quantification and valuation}

As the analysis adopted the societal perspective [25, 26], healthcare and non-healthcare resources were valued. Healthcare resources funded by the Italian National Health Service (INHS) included: cyclophosphamide, G-CSF, and plerixafor and their administration (inpatient [cyclophosphamide], day-hospital [plerixafor], or at-home [G-CSF] settings); hospitalization for febrile neutropenia (with cyclophosphamide only) and RBC and/or PLT transfusions; central venous catheter (with cyclophosphamide only); apheresis (inpatient or outpatient setting); and SC handling (processing, cryopreservation, and thawing) (Tables S1-S7).

Healthcare services provided in the outpatient, day-hospital, or inpatient settings were costed according to INHS outpatient or hospital tariffs [29-31], assumed to be a reasonable approximation of the real costs borne by healthcare facilities (Tables S11-S13) [32]. As previously reported $[33,34]$, the total daily cost of hospitalization was calculated by dividing the current INHS tariff by the mean duration of inpatient stay (days) [30].

To avoid double-counting (i.e., costing the same healthcare resource twice [25]), whenever the healthcare procedure cost included in the INHS tariff (e.g., RBC transfusion) was calculated separately, the INHS tariff was halved to account for the hotel cost of inpatient stay or day-hospital only [25, 35]. Cyclophosphamide, plerixafor, and G-CSF were costed at their last available prices (Table S2) [36].

Opportunity costs (i.e., the economic value of the best alternative use of the same resources [32]) for missed apheresis due to poor mobilization were also estimated. Costs for patients and their families consisted of out-of-pocket expenses, patient's productivity loss, and informal care provided by caregivers [25, 26]. Out-of-pocket expenses included all non-healthcare resources (e.g., transportation to and from healthcare facility and parking; Table S13) [37, 38].

One-half of patients were assumed to be employed (Table S4). The loss of working hours was valued using the gross wage rate (i.e., net wage + income taxes + social security contributions; Table S13) [39-41]. If the patient was unemployed or retired (i.e., $\geq 70$ years old), working time was replaced by leisure time, which, like caregivers' time, was costed at the take-home wage rate (net wage only; Table S13) [41, 42]. 
Costs were expressed in Euro (€) 2019 per patient and updated according to inflation rates for healthcare services or for general consumption whenever necessary [43]. As the time between mobilization and apheresis is expected not to exceed 1 year [5], costs and effectiveness were left undiscounted [17, 18, 25, 26, 44].

As this CEA model is not a clinical trial, study protocol approval by an ethics committee (including the questionnaire administered to oncohematologists) was not required by Italian legislation [45].

\section{Cost-effectiveness analysis}

Differences in costs (incremental cost $[\Delta \mathrm{C}]$ ) and the probability of successful apheresis (incremental effectiveness $[\Delta \mathrm{E}])$ for the mobilization schemes were calculated and summarized using the incremental cost-effectiveness ratio (ICER) [25, 26] (Supplementary Materials Definition 1).

\section{Statistical analysis}

The $95 \%$ confidence intervals (95\% CIs) were calculated by assigning a statistical distribution to most of the parameters included in the CEA model (i.e., event probabilities, resource utilization, and unit costs) [27, 35, 46-48]. (Tables S3-S13). For parameters without a statistical distribution, a range was reported (Tables S1 and S2). No hypothesis testing was performed.

\section{Sensitivity analyses}

The uncertainty of the base case ICER was addressed using one-way, probabilistic and scenario sensitivity analyses $[25,26,49]$.

\section{One-way sensitivity analysis}

Parameters included in the one-way sensitivity analysis were changed one at time, holding the others at their base case values [25, 26, 49]. For each parameter, the baseline estimate was replaced with the lower and upper limits of the $95 \%$ CI or range [27, 35, 46, 47]. Results of one-way sensitivity analysis were reported on a tornado chart as horizontal bars that depart from the baseline ICER. The wider the horizontal bar, the higher the variation in the base case ICER due to parameter variation.

\section{Probabilistic sensitivity analysis}

Probabilistic sensitivity analysis assessed parameter uncertainty linked to the base case ICER via a 10,000-iteration Monte Carlo simulation [25-27, 46]. For each Monte Carlo iteration, a random value from the statistical distribution for each parameter was used to generate $\Delta \mathrm{C}, \Delta \mathrm{E}$, and the resulting ICER [27, 46].

The conjoint density of 10,000 pairs of $\Delta \mathrm{C}$ and $\Delta \mathrm{E}$ for the healthcare program that ranked first in the base case CEA (treatment) was plotted on the cost-effectiveness plane, a two-dimensional surface divided into four sectors [50]. Each sector implies different ICER interpretations: the North East (NE) sector includes the iterations for which treatment is more costly and more effective than the comparator; the North West (NW) sector shows those iterations for which treatment is more costly and less effective than (i.e., is strongly dominated by) the comparator; in the South West (SW) sector treatment is less costly and less effective than the comparator; and in the South East (SE) sector the treatment is less costly and more effective than (i.e., strongly dominates) the comparator. The share of Monte Carlo iterations that fall below and to the right of the threshold value is defined as cost-effective.

An algebraic manipulation of the ICER (Net Monetary Benefit; Supplementary Materials Definition 2) [27, 46] used the Monte Carlo simulation results to construct the cost-effectiveness acceptability curve (Supplementary Materials Definition 3) and cost-effectiveness acceptability frontier (Supplementary Materials Definition 4), which summarize the probability for each mobilization strategy to be cost-effective or optimal versus its comparator for a given set of threshold values [27, 46, 51, 52]. As drug costs were kept constant, they were not included in sensitivity analyses [46].

\section{Scenario sensitivity analysis}

Scenario sensitivity analyses was performed to determine the impact of variation of one or more parameters at time on the baseline ICER [25, 49].

\section{Results}

\section{Decision tree}

Regardless of the SC mobilization scheme used, patients were assumed to enter the CEA model at a mean age of 57.62 years (Table 1 ).

In this model, patients undergoing chemotherapy-free and chemotherapy-based mobilization received a mean of 0.71 and 0.14 vials of on-demand plerixafor, respectively (Table 1 ). No other healthcare resource was used by patients who did not receive cyclophosphamide. Use of healthcare resources for those mobilized with cyclophosphamide + G-CSF ( \pm on-demand plerixafor) included time for inpatient cyclophosphamide administration, increased inpatient stay for febrile neutropenia, and administration of RBC and PLT transfusions (Table 1). 
Table 1 Summary of nonmonetary results of the costeffectiveness analysis model.

\begin{tabular}{|c|c|c|}
\hline Parameters & $\begin{array}{l}\text { G-CSF } \\
( \pm \text { on-demand PLX) }\end{array}$ & $\begin{array}{l}\text { CTX + G-CSF } \\
( \pm \text { on-demand PLX) }\end{array}$ \\
\hline \multicolumn{3}{|l|}{ Demographic and anthropometric parameters } \\
\hline Age, years, mean (range) & $57.62(51.38,62.38)$ & $57.62(51.38,62.38)$ \\
\hline Bodyweight, kg, mean (95\% CI) & $70.00(26.34,134.61)^{\mathrm{a}}$ & $70.00(26.34,134.61)^{\mathrm{a}}$ \\
\hline Height, cm, mean $(95 \% \mathrm{CI})$ & $170.00(136.68,203.32)^{\mathrm{a}}$ & $170.00(136.68,203.32)^{\mathrm{a}}$ \\
\hline \multicolumn{3}{|l|}{ Mobilization parameters, mean $(95 \% \mathrm{CI})$} \\
\hline Number of vials of on-demand PLX & $0.71(0.00,3.04)^{\mathrm{a}}$ & $0.14(0.00,1.22)^{\mathrm{a}}$ \\
\hline $\begin{array}{l}\text { Days of hospitalization for CTX } \\
\text { administration }\end{array}$ & 0 & $2.00(0.75,3.85)^{\mathrm{a}}$ \\
\hline $\begin{array}{l}\text { Days of hospitalization for febrile } \\
\text { neutropenia }\end{array}$ & 0 & $0.35(0.00,2.04)^{\mathrm{a}}$ \\
\hline Number of RBC transfusions & 0 & $0.24(0.00,1.68)^{\mathrm{a}}$ \\
\hline Number of PLT transfusions & 0 & $0.12(0.00,1.10)^{\mathrm{a}}$ \\
\hline \multicolumn{3}{|l|}{ Apheresis parameters, mean $(95 \% \mathrm{CI})$} \\
\hline Performed apheresis sessions & $2.00(0.75,3.85)^{\mathrm{a}}$ & $1.60(0.60,3.08)^{\mathrm{a}}$ \\
\hline $\begin{array}{l}\text { Missed apheresis sessions due to poor } \\
\text { mobilization }\end{array}$ & $0.48(0.18,0.92)^{\mathrm{a}}$ & $0.95(0.36,1.83)^{\mathrm{a}}$ \\
\hline \multicolumn{3}{|l|}{ Employment (patients only) ${ }^{\mathrm{b}}$} \\
\hline $\begin{array}{l}\text { Productivity losses, hours, mean } \\
(95 \% \text { CI) }\end{array}$ & $11.47(0.01,58.96)^{\mathrm{a}}$ & $78.08(17.50,182.84)^{\mathrm{a}}$ \\
\hline \multicolumn{3}{|l|}{ Informal care } \\
\hline Informal care, hours, mean $(95 \% \mathrm{CI})$ & $11.34(0.01,58.29)^{\mathrm{a}}$ & $76.46(16.85,180.59)^{\mathrm{a}}$ \\
\hline
\end{tabular}

$C I$ confidence interval, $C T X$ cyclophosphamide, G-CSF granulocyte colony-stimulating factor, $P L T$ platelet, $P L X$ plerixafor, $R B C$ red blood cell.

${ }^{\mathrm{a}}$ Gamma distribution 95\% CI [27, 47].

${ }^{\mathrm{b}}$ If the patient was unemployed, not engaged in housekeeping or retired ( $\geq 70$ years old), working time was replaced by leisure time.

Patients on chemotherapy-free and chemotherapy-based mobilization underwent 2.00 and 1.60 apheresis sessions, respectively, but missed 0.48 and 0.95 apheresis sessions due to poor mobilization. On average, patients on chemotherapy-free and chemotherapy-based mobilization lost 11.47 and 78.08 working hours, respectively, to receive healthcare services and needed 11.34 and 76.46 hours of informal care.

\section{Cost and cost-effectiveness analysis}

The total societal cost for G-CSF alone and cyclophosphamide + G-CSF ( \pm on-demand plerixafor) was $€ 8039.85$ and $€ 9238.44$ per patient, respectively (Table 2). The INHS-funded per patient cost for G-CSF alone and cyclophosphamide + G-CSF $( \pm$ on-demand plerixafor) reached $€ 7494.27$ and $€ 5984.30$, respectively $(93.21 \%$ and $64.77 \%$ of the overall cost). The out-of-pocket expenses were $€ 122.29$ and $€ 321.90$ per patient, respectively (1.52\% versus $3.49 \%$ of overall cost), and productivity losses plus informal care costs were $€ 423.30$ and $€ 2932.24$, respectively $(5.27 \%$ versus $31.74 \%$ of overall cost). For both healthcare programs, the cost-drivers were drugs prescribed during mobilization $(61.29 \%$ and $20.86 \%$ of overall cost).
In the CEA, G-CSF alone versus cyclophosphamide + G-CSF ( \pm on-demand plerixafor) was associated with a $\Delta \mathrm{C}$ of $-€ 1198.59$ (i.e., incremental saving) and an $\Delta \mathrm{E}$ of +0.052 (i.e., an incremental probability of a successful 4 million-CD34 ${ }^{+}$apheresis), indicating that G-CSF alone was strongly dominant over cyclophosphamide + G-CSF ( \pm ondemand plerixafor; Table 3).

\section{Sensitivity analyses}

\section{One-way sensitivity analysis}

As shown in the tornado chart (Fig. 1), when expressed in percentages, the largest variations in baseline ICER were observed with changes in the number of plerixafor vials administered (from $-282.72 \%$ to $+191.02 \%$ versus base case ICER). Variation in the probability of plerixafor administration affected baseline findings moderately (from $-45.32 \%$ to $+103.63 \%$ versus base case ICER).

\section{Probabilistic sensitivity analysis}

Of the 10,000 Monte Carlo iterations, chemotherapyfree mobilization was more costly and more effective 
Table 2 Base case analysis - Costs per patient (€2019).

\begin{tabular}{|c|c|c|c|c|}
\hline Cost items & G-CSF ( \pm on-demand PLX) & $\begin{array}{l}\text { Proportion of overall } \\
\text { cost }(\%)^{\mathrm{a}}\end{array}$ & $\begin{array}{l}\text { CTX + G-CSF } \\
( \pm \text { on-demand PLX) }\end{array}$ & $\begin{array}{l}\text { Proportion of overall } \\
\text { cost }(\%)^{\mathrm{a}}\end{array}$ \\
\hline \multicolumn{5}{|l|}{ INHS cost } \\
\hline \multicolumn{5}{|l|}{ Mobilization } \\
\hline Drugs & $€ 4927.05$ & 61.29 & $€ 1926.87$ & 20.86 \\
\hline$C T X$ & $€ 0.00$ & - & $€ 128.13$ & 6.65 \\
\hline$G-C S F$ & $€ 1332.52$ & 27.04 & $€ 1110.43$ & 57.63 \\
\hline$P L X$ & $€ 3594.53$ & 72.96 & $€ 688.31$ & 35.72 \\
\hline Administration & $€ 92.02$ & 1.14 & $€ 439.69$ & 4.76 \\
\hline CTX & $€ 0.00$ & - & $€ 422.07$ & 96.00 \\
\hline$G-C S F$ & $€ 0.00$ & - & $€ 0.00$ & 0.00 \\
\hline$P L X$ & $€ 92.02$ & 100 & $€ 17.62$ & 4.00 \\
\hline Full blood count & $€ 4.76$ & 0.06 & $€ 4.76$ & 0.05 \\
\hline Central venous catheter & $€ 0.00$ & - & $€ 150.58$ & 1.63 \\
\hline Febrile neutropenia & $€ 0.00$ & - & $€ 149.15$ & 1.61 \\
\hline Transfusions & $€ 0.00$ & - & $€ 739.27$ & 8.00 \\
\hline$R B C$ & $€ 0.00$ & - & $€ 495.89$ & 67.08 \\
\hline$P L T$ & $€ 0.00$ & - & $€ 243.38$ & 32.92 \\
\hline \multicolumn{5}{|l|}{ Apheresis } \\
\hline Procedures & $€ 1144.45$ & 14.23 & $€ 1247.99$ & 13.51 \\
\hline Flow cytometry & $€ 51.00$ & 4.46 & $€ 51.00$ & 4.09 \\
\hline Full blood count & $€ 4.76$ & 0.42 & $€ 12.02$ & 0.96 \\
\hline Apheresis & $€ 877.98$ & 76.72 & $€ 767.92$ & 61.53 \\
\hline Missed apheresis & $€ 210.72$ & 18.41 & $€ 417.04$ & 33.42 \\
\hline Stem cell handling & $€ 1326.00$ & 16.49 & $€ 1326.00$ & 14.35 \\
\hline Processing & $€ 668.00$ & 50.38 & $€ 668.00$ & 50.38 \\
\hline Freezing & $€ 510.00$ & 38.46 & $€ 510.00$ & 38.46 \\
\hline Thawing & $€ 148.00$ & 11.16 & $€ 148.00$ & 11.16 \\
\hline Total (A) & $€ 7494.27$ & $93.21 \%$ & $€ 5984.3$ & $64.77 \%$ \\
\hline \multicolumn{5}{|c|}{ Patient and their family cost (out-of-pocket expenses) } \\
\hline Transportation & $€ 92.29$ & 1.15 & $€ 242.7$ & 2.63 \\
\hline Parking & $€ 30.00$ & 0.37 & $€ 79.2$ & 0.86 \\
\hline Total (B) & $€ 122.29$ & $1.52 \%$ & $€ 321.9$ & $3.49 \%$ \\
\hline \multicolumn{5}{|c|}{ Patient and their family cost (Patient and care-giver's time) } \\
\hline Patient loss of working days ${ }^{\mathrm{b}}$ & $€ 249.17$ & 3.10 & $€ 1695.84$ & 18.36 \\
\hline Informal care & $€ 174.13$ & 2.17 & $€ 1236.4$ & 13.38 \\
\hline Total (C) & $€ 423.3$ & $5.27 \%$ & $€ 2932.24$ & $31.74 \%$ \\
\hline Overall cost $(\mathrm{A}+\mathrm{B}+\mathrm{C})$ & $€ 8039.85$ & $100.00 \%$ & $€ 9238.44$ & $100.00 \%$ \\
\hline
\end{tabular}

CTX cyclophosphamide, $G$-CSF granulocyte colony-stimulating factor, INHS Italian National Health Service, $P L T$ platelets, $P L X$ plerixafor, $R B C$ red blood cells.

${ }^{a}$ The percentage of each category/item cost on the overall cost is reported in normal font. Italic font denotes the percentage of each sub-item on the category/item cost.

${ }^{\mathrm{b}}$ If the patient was unemployed, not engaged in housekeeping or retired (i.e., $\geq 70$ years old), working time was replaced by leisure time.

than chemotherapy-based mobilization (NE sector of the cost-effectiveness plane) in 2314 (23.14\%). For 440 iterations $(4.40 \%), \mathrm{G}-\mathrm{CSF}$ alone ( \pm on-demand plerixafor) was more costly and less effective than chemotherapy-based mobilization (NW sector). In 5992 iterations $(59.92 \%)$, chemotherapy-free mobilization was less costly and more effective (SE sector) and strongly dominated chemotherapy-based mobilization. 
Table 3 Base case cost-effectiveness analysis (€2019).

\begin{tabular}{llllll}
\hline Mobilization schemes & Cost & Effectiveness $^{\mathrm{a}}$ & $\Delta \mathrm{C}$ & $\Delta \mathrm{E}$ & ICER $(\Delta \mathrm{C} / \Delta \mathrm{E})$ \\
\hline $\mathrm{CTX} 4 \mathrm{~g} / \mathrm{m}^{2}+\mathrm{G}-\mathrm{CSF} \pm$ on-demand PLX & $€ 9238.44$ & 0.714 & - & - & - \\
G-CSF \pm on-demand PLX & $€ 8039.85$ & 0.766 & $-€ 1198.59$ & 0.052 & strongly dominant \\
\hline
\end{tabular}

$\Delta C$ incremental cost, $\Delta E$ incremental effectiveness, $C T X$ cyclophosphamide, $G$-CSF granulocyte colony-stimulating factor, ICER incremental costeffectiveness ratio for G-CSF \pm on-demand PLX vs CTX $4 \mathrm{~g} / \mathrm{m}^{2}+\mathrm{G}-\mathrm{CSF} \pm$ on-demand PLX, PLX plerixafor.

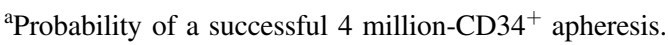

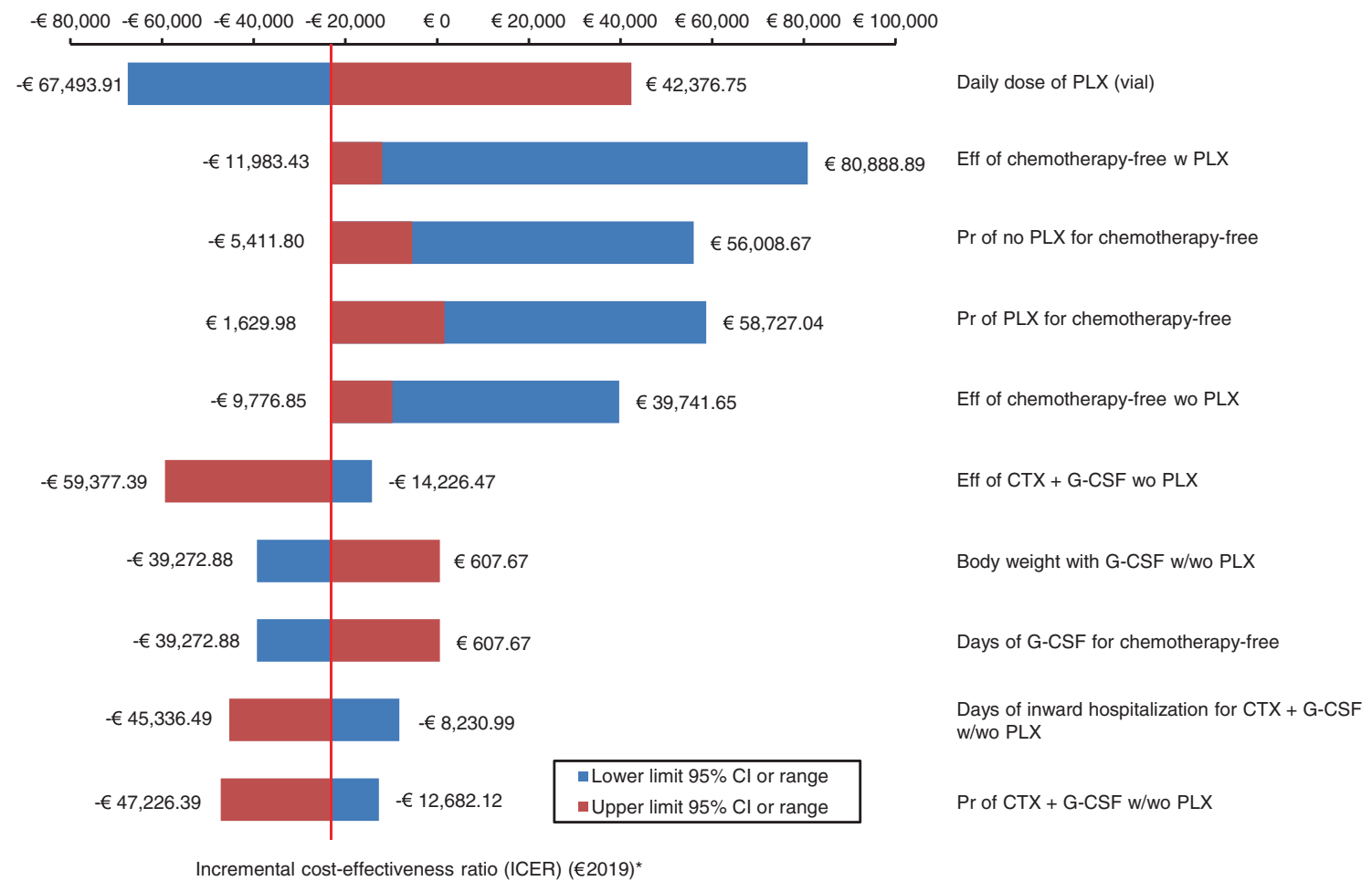

Fig. 1 Tornado chart showing one-way sensitivity analysis (€2019) of G-CSF \pm on-demand plerixafor versus cyclophosphamide $4 \mathrm{~g}$ / $\mathbf{m}^{2}+\mathbf{G}-\mathbf{C S F} \pm$ on-demand plerixafor. The base case ICER for G$\mathrm{CSF} \pm$ on-demand plerixafor was $-€ 23,192.47$ (indicated by the red

Eventually, for 1254 iterations (12.54\%), chemotherapyfree mobilization was less costly and less effective (SW sector) than chemotherapy-based mobilization (Fig. 2).

The likelihood of G-CSF ( \pm on-demand plerixafor) being cost-effective was $72.46 \%, 84.24 \%$, and $86.12 \%$ when the threshold was $€ 0, € 25,000$, and $€ 40,000$, respectively (Fig. 3).

The cost-effectiveness acceptability frontier showed that G-CSF ( \pm on-demand plerixafor) starts to be the optimal alternative from a societal willingness to pay (WTP) of $€ 0$ onwards (Fig. 4).

\section{Scenario sensitivity analysis}

For most of the assumptions tested in the scenario sensitivity analysis, the chemotherapy-free mobilization regimen retained vertical line) and was strongly dominant. CTX cyclophosphamide, Eff effectiveness, $G$-CSF granulocyte colony-stimulating factor, ICER incremental cost-effectiveness ratio, $P L X$ plerixafor, $\operatorname{Pr}$ probability, $w$ with, wo without.

its strong dominance (Table 4). When both mobilization regimens were assumed to be equally effective, the chemotherapyfree regimen was weakly dominant (i.e., less costly but equally effective) versus the chemotherapy-based regimen.

\section{Discussion}

To our knowledge, this is the first Italian CEA to compare chemotherapy-free with chemotherapy-based mobilization ( \pm on-demand plerixafor) in patients with $\mathrm{MM}$ using a decision model populated with parameters elicited from a panel of experienced oncohematologists. While our basecase CEA shows that G-CSF ( \pm on-demand plerixafor) is strongly dominant, probabilistic sensitivity analysis 


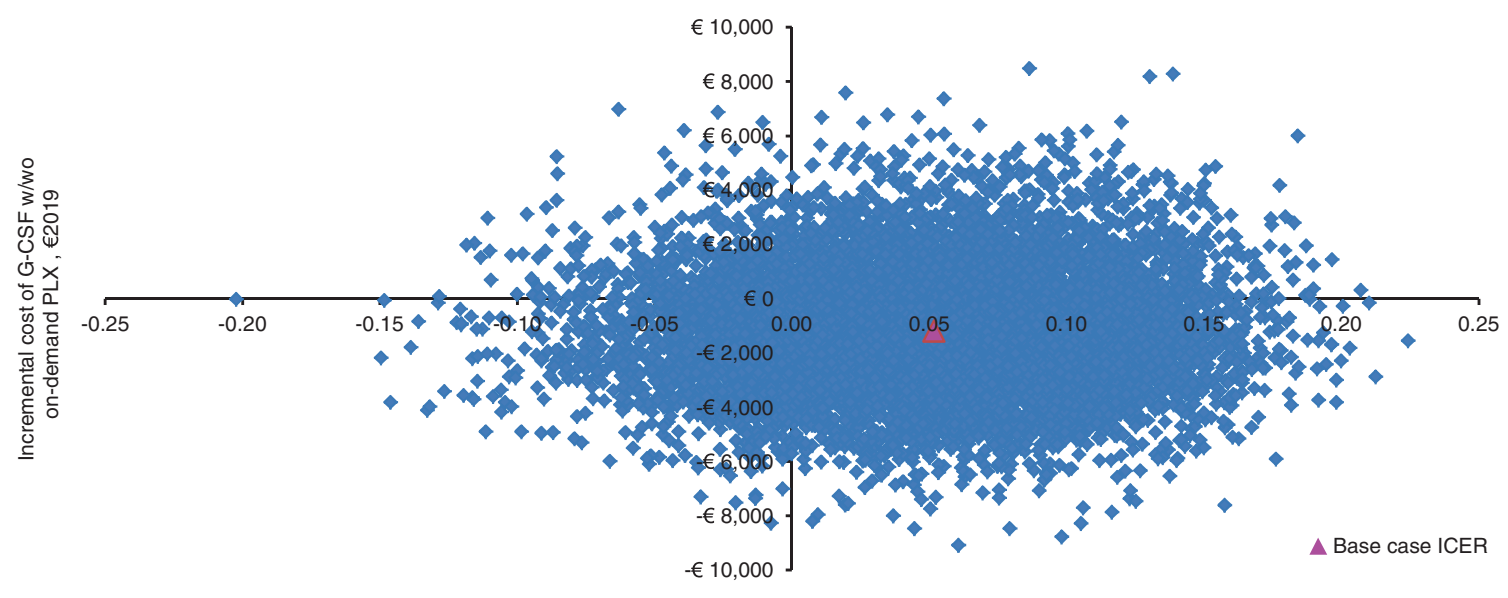

Incremental effectiveness of G-CSF alone w/wo on-demand PLX

Fig. 2 Cost-effectiveness plane showing probabilistic sensitivity analysis (€2019) of G-CSF \pm on-demand plerixafor versus cyclophosphamide $4 \mathrm{~g} / \mathrm{m}^{2}+\mathrm{G}-\mathrm{CSF} \pm$ on-demand plerixafor. The base case ICER for G-CSF \pm on-demand plerixafor was strongly dominant. G-CSF granulocyte colony-stimulating factor, ICER incremental costeffectiveness ratio, PLX plerixafor, w with, wo without.

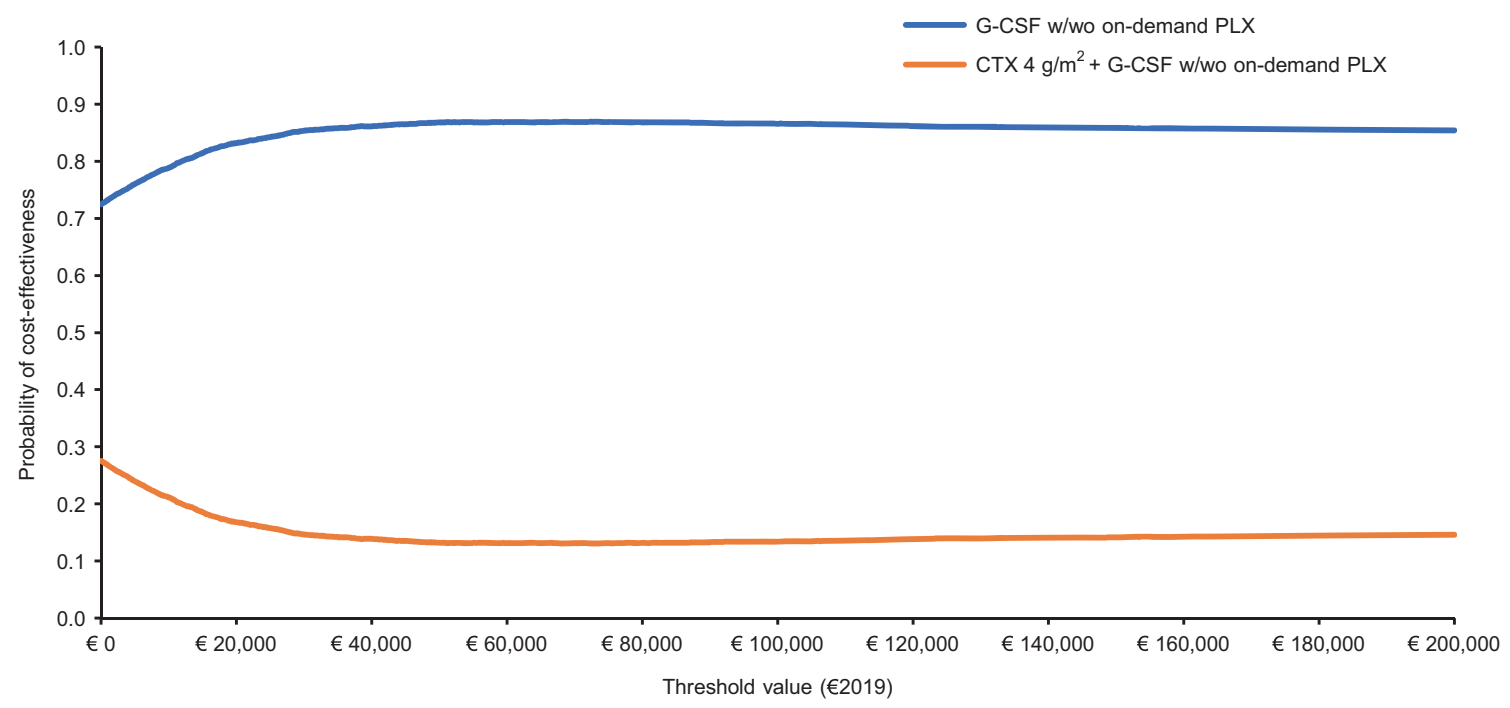

Fig. 3 Cost-effectiveness acceptability curve showing probabilistic sensitivity analysis (€2019) of G-CSF \pm on demand plerixafor versus cyclophosphamide $4 \mathrm{~g} / \mathrm{m}^{2}+\mathrm{G}-\mathrm{CSF} \pm$ on-demand plerixafor.

suggests that this mobilization regimen has a high probability of being cost-effective.

Previous Italian studies have estimated healthcare resource utilization and costs of mobilization and collection of SC in MM, lymphoma, and other blood malignancies [53-55], and provided ICER for a successful apheresis in MM patients on chemotherapy-based mobilization [22]. However, these studies followed the hospital viewpoint (i.e. costs calculated only for the healthcare resources consumed by MM patients in the inpatient and day-hospital settings), whereas our CEA model adopted the wider societal perspective, as chemotherapy-based mobilization may affect patients' (and their families') resources and time more severely than chemotherapy-free schemes $[18,56]$.
The base case ICER for G-CSF \pm on-demand plerixafor was strongly dominant. CTX cyclophosphamide, G-CSF granulocyte colonystimulating factor, PLX plerixafor, w with, wo without.

Most of the economic evaluation of healthcare programmes comparing mobilization with versus without plerixafor focused on cost per quality-adjusted life year (QALY) gained. QALY is a disease non-specific, nonclinical effectiveness measure that weights patients' survival for health-related quality of life (utility) [25, 26].

Cost-utility analyses performed on patients with nonHodgkin's lymphoma [57] or MM [58] reported incremental cost-utility ratios (ICUR) of US\$14,735 and US $\$ 52,813$, respectively, with plerixafor administration (2010 values). When assessing the sustainability of the cost per QALY gained, decision-makers should consider countryspecific threshold values. WTPs of US\$50,000 and US $\$ 100,000$ per QALY gained are often quoted for North 


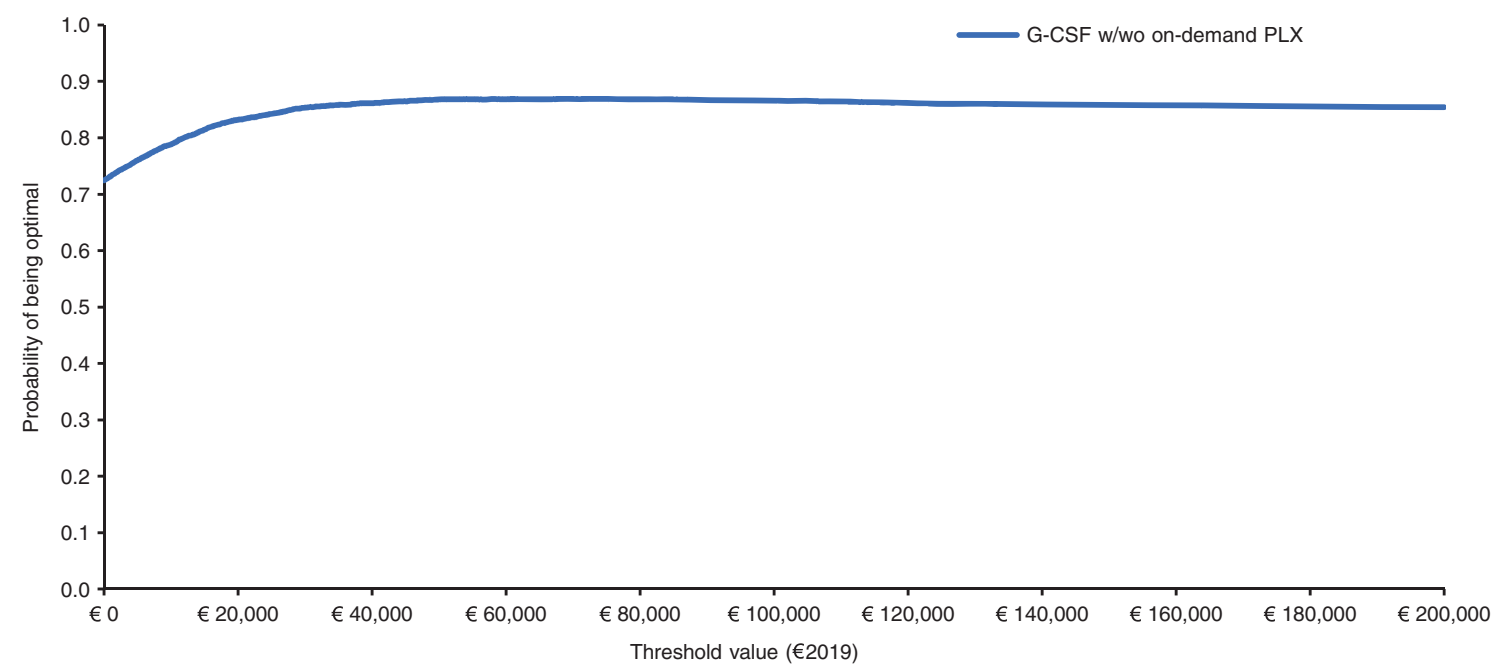

Fig. 4 Cost-effectiveness acceptability frontier showing probabilistic sensitivity analysis (€2019) for GCS-F \pm on-demand plerixafor versus cyclophosphamide $4 \mathrm{~g} / \mathrm{m}^{2}+\mathrm{G}-\mathrm{CSF} \pm$ on-demand plerixafor. The base case ICER for GCS-F \pm on-demand plerixafor was strongly dominant. GCS-F \pm plerixafor was the optimal healthcare program from a threshold value of $€ 0.00$ onwards. G-CSF granulocyte colony-stimulating factor, PLX plerixafor, w with, wo without.

Table 4 Scenario sensitivity analysis (€2019).

\begin{tabular}{|c|c|c|c|c|c|}
\hline Mobilization schemes & Cost & Effectiveness $^{\mathrm{a}}$ & $\Delta \mathrm{C}$ & $\Delta \mathrm{E}$ & $\operatorname{ICER}(\Delta \mathrm{C} / \Delta \mathrm{E})$ \\
\hline \multicolumn{6}{|l|}{ Base case analysis } \\
\hline CTX $4 \mathrm{~g} / \mathrm{m}^{2}+\mathrm{G}-\mathrm{CSF} \pm$ on-demand PLX & $€ 9238.44$ & 0.714 & - & - & - \\
\hline G-CSF \pm on-demand PLX & $€ 8039.85$ & 0.766 & $-€ 1198.59$ & 0.052 & strongly dominant \\
\hline \multicolumn{6}{|c|}{ Scenario sensitivity analysis - Same effectiveness for chemo-free and chemo-based mobilization regimens } \\
\hline CTX $4 \mathrm{~g} / \mathrm{m}^{2}+\mathrm{G}-\mathrm{CSF} \pm$ on-demand PLX & $€ 9238.44$ & 0.766 & - & - & - \\
\hline G-CSF \pm on-demand PLX & $€ 8039.85$ & 0.766 & $-€ 1198.59$ & 0.000 & weakly dominant \\
\hline \multicolumn{6}{|c|}{ Scenario sensitivity analysis - Reversed effectiveness for chemo-free and chemo-based mobilization regimens } \\
\hline CTX $4 \mathrm{~g} / \mathrm{m}^{2}+\mathrm{G}-\mathrm{CSF} \pm$ on-demand PLX & $€ 9238.44$ & 0.766 & - & - & - \\
\hline G-CSF \pm on-demand PLX & $€ 8039.85$ & 0.714 & $-€ 1198.59$ & & $€ 23,049.81$ \\
\hline
\end{tabular}

Scenario sensitivity analysis - CTX administration costed with DH tariff for all patients on chemo-based mobilization regimen
CTX $4 \mathrm{~g} / \mathrm{m}^{2}+\mathrm{G}-\mathrm{CSF} \pm$ on-demand PLX
$€ 8438.32$
0.714
$€ 8708.42$
0.766
$€ 270,09$
0.052
$€ 5226.29$

Scenario sensitivity analysis - Reversed percentages for inward and outpatient management of neutropenia for all patients on chemo-based mobilization regimen
CTX $4 \mathrm{~g} / \mathrm{m}^{2}+\mathrm{G}-\mathrm{CSF} \pm$ on-demand PLX
$€ 9114.88$
0.714
G-CSF \pm on-demand PLX
$€ 8039.85$
0.766
$-€ 1075.03$
0.052
strongly dominant

Scenario sensitivity analysis - Central venous catheter for all patients on chemo-free mobilization regimen undegoing apheresis
CTX $4 \mathrm{~g} / \mathrm{m}^{2}+\mathrm{G}-\mathrm{CSF} \pm$ on-demand PLX
$€ 9238.44$
0.714
$\mathrm{G}-\mathrm{CSF} \pm$ on-demand PLX
$€ 8110.62$
0.766
$-€ 1127.81$
0.052
strongly dominant

Scenario sensitivity analysis - Outpatient apheresis for all patients on chemo-based mobilization regimen

$\begin{array}{llllll}\text { CTX } 4 \text { g/m² }+ \text { G-CSF } \pm \text { on-demand PLX } & € 9142.26 & 0.714 & - & - & - \\ \text { G-CSF } \pm \text { on-demand PLX } & € 8039.85 & 0.766 & -€ 1102.41 & 0.052 & \text { strongly dominant }\end{array}$

$\Delta C$ incremental cost, $\Delta E$ incremental effectiveness, $C T X$ cyclophosphamide, DH day-hospital, $G$-CSF granulocyte colony-stimulating factor, ICER incremental cost-effectiveness ratio for G-CSF \pm on-demand PLX vs CTX $4 \mathrm{~g} / \mathrm{m}^{2}+\mathrm{G}-\mathrm{CSF} \pm$ on-demand PLX, PLX plerixafor.

${ }^{a}$ Probability of a successful 4 million-CD $34^{+}$apheresis.

America [59, 60], whereas the National Institute for Health and Care Excellence (NICE) more recently confirmed an acceptability range of UK£20,000-UK£30,000 per QALY gained in England and Wales [61]. In 2009, the Italian Association of Health Economics proposed a WTP threshold similar to that set by NICE (€25,000-€40,000) [44]. 
However, the implicit threshold value adopted by the Italian Medicines Agency for reimbursing oncology drugs has been estimated at €87,330 (2014 values) [62].

Even though the cost per QALY gained remains the determinant for rationing in the healthcare sector [25, 26], our analysis may contribute to defining the economic sustainability of successful apheresis with chemotherapy-free mobilization ( \pm on-demand plerixafor) in MM patients. This topic warrants further investigation, due to the lack of costeffectiveness thresholds for clinical effectiveness outcomes (e.g., successful apheresis). The absence of a specific WTP for successful mobilization may be the main reason why one UK CEA on plerixafor concluded that no opinion on its affordability could be made (ICERs of UK£12,608-UK $£ 15,450$; year of currency not reported) [20]. Similarly, a Czech decision tree-supported CEA model reported a $\Delta \mathrm{E}$ of $10 \%$ with G-CSF \pm plerixafor versus G-CSF ( \pm chemotherapy), with an ICER of US\$11,803 for successful mobilization (2013 values) [23]. However, no recommendation was provided to the national decision-makers on whether or not plerixafor was a "good value for money" option [23]. In contrast, a model-based CEA highlighted the unaffordability for the Jordan healthcare system of G-CSF + plerixafor versus G-CSF ( \pm cyclophosphamide) with an ICER of US $\$ 244,714$ per successful apheresis (year of currency not reported) [17].

A US study comparing low-dose cyclophosphamide $(1.5-2.0 \mathrm{~g} / \mathrm{kg} /$ day $)+$ G-CSF versus G-CSF + plerixafor in MM patients undergoing mobilization reported no significant difference in effectiveness with regard to collection of $\geq 2, \geq 5$, or $\geq 10$ million $\mathrm{CD} 34^{+}$cells $/ \mathrm{kg}$ [18]. In the same study, G-CSF + plerixafor had a $\Delta \mathrm{C}$ of +US\$6475.20 versus G-CSF + cyclophosphamide (total costs US $\$ 28,980.00$ versus US $\$ 22,504.80 ; p=0.001 ; 2012$ values). As the study was conducted from the Medicare and Medicaid perspective, the cost difference was exclusively due to higher healthcare resource utilization with chemotherapyfree mobilization [18]. Further investigation from a societal perspective may reveal whether the increased costs for chemotherapy-based mobilization due to higher out-ofpocket expenses, patient's time consumption, and informal care associated with cyclophosphamide administration bridge the economic gap between the two mobilization strategies [18]. In another US study in MM patients, mobilization with G-CSF + plerixafor was more costly (total cost US $\$ 28,980.00$ versus US\$19,626.50; $p=0.001$; 2012 values) and more effective (higher percentage of 2-10 million $\mathrm{CD}^{+} 4^{+}$cells collected; $\left.p=0.01-0.001\right)$ than $\mathrm{G}-$ CSF + low-dose cyclophosphamide [19]. Following the French healthcare system viewpoint, G-CSF + plerixafor was more costly (mean cost $€ 10,958.00$ versus $€ 5097.00$; $p<0.0001 ; 2012$ values) and more effective (autologous SCT $86 \%$ versus $67 \% ; p=0.02$ ) than high-dose cyclophosphamide in MM patients [63]. However, a CEA was not conducted in these studies.

Furthermore, with the currently available therapeutic options for MM patients, including agents that prevent exposure to conventional chemotherapy and their associated systemic toxicity, the placement and role of cyclophosphamide as a "pure" SC mobilizing agent appears questionable.

Our research has three main limitations. First, the parameters of the CEA model were obtained from a panel of Italian oncohematologists who were introduced to each other during a meeting to discuss the feasibility of this study. Therefore, the Delphi method [64] was not applied, as the requirement of panelist anonymity could not be met. Second, following previously research [23, 58], we performed a model-based CEA rather than an empirical one using clinical trial data [20-22]. Given the advantages and disadvantages of model-based versus empirical studies [25-27, 65, 66], the robustness of our base-case findings was checked and confirmed via three sensitivity analyses. Future empirical CEAs on chemotherapy-based versus chemotherapy-free mobilization ( \pm on-demand plerixafor) in MM patients will hopefully provide more reliable ICERs [56]. Third, the mean age of the notional patients entering the Markov model is lower than the one reported in other research [3]. However, one-way sensitivity analysis proved that patients' age was not among the ten parameters that caused the most relevant departures from the basecase ICER.

In conclusion, our study shows that, from a societal perspective, chemotherapy-free mobilization ( \pm on-demand plerixafor) is a cost-effective (and possibly strongly dominant) healthcare program for patients with $\mathrm{MM}$ who are eligible for autologous SCT in Italy.

Acknowledgements We thank Sarah Greig, $\mathrm{PhD}$, of Springer Healthcare Communications, who provided English language editing services. This medical writing assistance was funded by Sanofi S.p.A.

Funding This study was funded by Sanofi S.p.A., which has had no influence of the interpretation of data and the final conclusions drawn.

\section{Compliance with ethical standards}

Conflict of interest CL has received research grants, speaker or consultancy fees from Boehringer Ingelheim Italia S.p.A., CSL Behring S. p.A., Ferring S.p.A., Ipsen S.p.A., Roche S.p.A., Sanofi S.p.A., Santen $\mathrm{GmbH}$, and Shire Italia S.p.A.; LC has received consultancy fees from Sanofi S.p.A.; FL has received consultancy fees from AbbVie s.r.l. and Sanofi S.p.A.; DL has received consultancy fees from Sanofi S.p.A. and Sandoz S.p.A.; GM declares no disclosures; LP has received consultancy fees from Sanofi S.p.A.; RS has received consultancy fees from Sanofi S.p.A.

Publisher's note Springer Nature remains neutral with regard to jurisdictional claims in published maps and institutional affiliations. 
Open Access This article is licensed under a Creative Commons Attribution 4.0 International License, which permits use, sharing, adaptation, distribution and reproduction in any medium or format, as long as you give appropriate credit to the original author(s) and the source, provide a link to the Creative Commons license, and indicate if changes were made. The images or other third party material in this article are included in the article's Creative Commons license, unless indicated otherwise in a credit line to the material. If material is not included in the article's Creative Commons license and your intended use is not permitted by statutory regulation or exceeds the permitted use, you will need to obtain permission directly from the copyright holder. To view a copy of this license, visit http://creativecommons. org/licenses/by/4.0/.

\section{References}

1. Alegre A, Tomas JF, Martinez-Chamorro C, Gil-Fernandez JJ, Fernandez-Villalta MJ, Arranz R, et al. Comparison of peripheral blood progenitor cell mobilization in patients with multiple myeloma: high-dose cyclophosphamide plus GM-CSF vs G-CSF alone. Bone Marrow Transpl. 1997;20:211-7. https://doi.org/10. 1038/sj.bmt.1700867. e-pub ahead of print 1997/08/01

2. Goldschmidt H, Hegenbart U, Wallmeier M, Hohaus S, Haas R. Factors influencing collection of peripheral blood progenitor cells following high-dose cyclophosphamide and granulocyte colonystimulating factor in patients with multiple myeloma. Br J Haematol. 1997;98:736-44. https://doi.org/10.1046/j.1365-2141. 1997.2783095.x. e-pub ahead of print 1997/10/23

3. Mohty M, Hubel K, Kroger N, Aljurf M, Apperley J, Basak GW, et al. Autologous haematopoietic stem cell mobilisation in multiple myeloma and lymphoma patients: a position statement from the European Group for Blood and Marrow Transplantation. Bone Marrow Transpl. 2014;49:865-72. https://doi.org/10.1038/bmt. 2014.39. e-pub ahead of print 2014/04/02

4. Petrucci MT, Avvisati G, La Verde G, De Fabritiis P, Ribersani M, Palumbo G, et al. Intermediate-dose cyclophosphamide and granulocyte colony-stimulating factor is a valid alternative to high-dose cyclophosphamide for mobilizing peripheral blood CD34+ cells in patients with multiple myeloma. Acta Haematol. 2003;109:184-8. https://doi.org/10.1159/000070967. e-pub ahead of print 2003/07/11

5. Hamadani M, Kochuparambil ST, Osman S, Cumpston A, Leadmon S, Bunner P, et al. Intermediate-dose versus low-dose cyclophosphamide and granulocyte colony-stimulating factor for peripheral blood stem cell mobilization in patients with multiple myeloma treated with novel induction therapies. Biol Blood Marrow Transpl. 2012;18:1128-35. https://doi.org/10.1016/j. bbmt.2012.01.005. e-pub ahead of print 2012/01/18

6. Hiwase DK, Bollard G, Hiwase S, Bailey M, Muirhead J, Schwarer AP. Intermediate-dose CY and G-CSF more efficiently mobilize adequate numbers of PBSC for tandem autologous PBSC transplantation compared with low-dose $\mathrm{CY}$ in patients with multiple myeloma. Cytotherapy. 2007;9:539-47. https://doi.org/ 10.1080/14653240701452800. e-pub ahead of print 2007/09/21

7. Jantunen E, Putkonen M, Nousiainen T, Pelliniemi TT, Mahlamaki E, Remes K. Low-dose or intermediate-dose cyclophosphamide plus granulocyte colony-stimulating factor for progenitor cell mobilisation in patients with multiple myeloma. Bone Marrow Transpl. 2003;31:347-51. https://doi.org/10.1038/ sj.bmt.1703840. e-pub ahead of print 2003/03/14

8. Dingli D, Nowakowski GS, Dispenzieri A, Lacy MQ, Hayman S, Litzow MR, et al. Cyclophosphamide mobilization does not improve outcome in patients receiving stem cell transplantation for multiple myeloma. Clin Lymphoma Myeloma. 2006;6:384-8.
https://doi.org/10.3816/CLM.2006.n.014. e-pub ahead of print $2006 / 04 / 28$

9. Oyekunle A, Shumilov E, Kostrewa P, Burchert A, Trumper L, Wuchter P, et al. Chemotherapy-based stem cell mobilization does not result in significant paraprotein reduction in myeloma patients in the era of novel induction regimens. Biol Blood Marrow Transpl. 2018;24:276-81. https://doi.org/10.1016/j.bbmt.2017.10. 008. e-pub ahead of print 2017/10/19

10. Uy GL, Costa LJ, Hari PN, Zhang MJ, Huang JX, Anderson KC, et al. Contribution of chemotherapy mobilization to disease control in multiple myeloma treated with autologous hematopoietic cell transplantation. Bone Marrow Transpl. 2015;50:1513-8. https://doi.org/10.1038/bmt.2015.190. e-pub ahead of print 2015/ $08 / 25$

11. Andreola G, Vanazzi A, Radice D, Babic A, Rabascio C, Negri M, et al. Who should be really considered as a poor mobilizer in the plerixafor era? Transfus Apher Sci. 2012;47:27-32. https://doi.org/ 10.1016/j.transci.2012.03.004. e-pub ahead of print 2012/04/07

12. DiPersio JF, Stadtmauer EA, Nademanee A, Micallef IN, Stiff PJ, Kaufman JL, et al. Plerixafor and G-CSF versus placebo and GCSF to mobilize hematopoietic stem cells for autologous stem cell transplantation in patients with multiple myeloma. Blood. 2009;113:5720-6. https://doi.org/10.1182/blood-2008-08-174946. e-pub ahead of print 2009/04/14

13. Lanza F, Lemoli RM, Olivieri A, Laszlo D, Martino M, Specchia $\mathrm{G}$, et al. Factors affecting successful mobilization with plerixafor: an Italian prospective survey in 215 patients with multiple myeloma and lymphoma. Transfusion. 2014;54:331-9. https://doi.org/ 10.1111/trf.12265. e-pub ahead of print 2013/06/21

14. Lanza F, Gardellini A, Laszlo D, Martino M. Plerixafor: what we still have to learn. Expert Opin Biol Ther. 2015;15:143-7. https:// doi.org/10.1517/14712598.2015.971750. e-pub ahead of print 2014/10/16

15. Sanchez-Ortega I, Querol S, Encuentra M, Ortega S, Serra A, Sanchez-Villegas JM, et al. Plerixafor in patients with lymphoma and multiple myeloma: effectiveness in cases with very low circulating $\mathrm{CD} 34+$ cell levels and preemptive intervention vs remobilization. Bone Marrow Transpl. 2015;50:34-39. https://doi. org/10.1038/bmt.2014.196. e-pub ahead of print 2014/09/16

16. Clark RE, Bell J, Clark JO, Braithwaite B, Vithanarachchi U, McGinnity N, et al. Plerixafor is superior to conventional chemotherapy for first-line stem cell mobilisation, and is effective even in heavily pretreated patients. Blood Cancer J 2014; 4: e255. e-pub ahead of print 2014/11/02; https://doi.org/10.1038/bcj.2014.79

17. Abdel-Rahman F, Tuffaha HW, Sharma S, Jazar HA, Hussein N, Saad A, et al. GCSF with or without chemotherapy compared to plerixafor with GCSF as salvage mobilization regimen in patients with multiple myeloma and lymphoma: collection effectiveness and cost effectiveness analysis. J Oncol Pharm Pract 2014; 20 : 130-6. e-pub ahead of print 2013/05/17; https://doi.org/10.1177/ 1078155213484785 .

18. Awan F, Kochuparambil ST, Falconer DE, Cumpston A, Leadmon S, Watkins $\mathrm{K}$, et al. Comparable efficacy and lower cost of PBSC mobilization with intermediate-dose cyclophosphamide and G-CSF compared with plerixafor and G-CSF in patients with multiple myeloma treated with novel therapies. Bone Marrow Transplant 2013; 48: 1279-84. e-pub ahead of print 2013/04/16; https://doi.org/10.1038/bmt.2013.52.

19. Chaudhary L, Awan F, Cumpston A, Leadmon S, Watkins K, Tse W, et al. Peripheral blood stem cell mobilization in multiple myeloma patients treat in the novel therapy-era with plerixafor and G-CSF has superior efficacy but significantly higher costs compared to mobilization with low-dose cyclophosphamide and GCSF. J Clin Apher. 2013;28:359-67. https://doi.org/10.1002/jca. 21280. e-pub ahead of print 2013/06/15 
20. Martin AP, Richards S, Haycox A, Houten R, McLeod C, Braithwaite B, et al. Evaluating the use of plerixafor in stem cell mobilisation - an economic analysis of the PHANTASTIC trial. J Clin Apher. 2016;31:434-42. https://doi.org/10.1002/jca.21433. e-pub ahead of print 2015/09/30

21. Micallef IN, Sinha S, Gastineau DA, Wolf R, Inwards DJ, Gertz MA, et al. Cost-effectiveness analysis of a risk-adapted algorithm of plerixafor use for autologous peripheral blood stem cell mobilization. Biol Blood Marrow Transpl. 2013;19:87-93. https:// doi.org/10.1016/j.bbmt.2012.08.010. e-pub ahead of print 2012/ $08 / 28$

22. Milone G, Martino M, Leotta S, Spadaro A, Zammit V, Cupri A, et al. Cost-effectiveness of on-demand plerixafor added to chemotherapy and granulocyte-colony stimulating factor for peripheral blood stem cell mobilization in multiple myeloma. Leuk Lymphoma. 2018;59:42-48. https://doi.org/10.1080/10428194. 2017.1324161. e-pub ahead of print 2017/06/03

23. Tichopád A, Vitova V, Koristek Z, Lysak D. Cost-effectiveness of hematopoietic stem cell mobilization strategies including plerixafor in multiple myeloma and lymphoma patients. J Clin Apher. 2013;28:395-403. https://doi.org/10.1002/jca.21290. e-pub ahead of print 2013/08/08

24. Lohr SL Sampling: design and analysis, 2nd edn Brooks/Cole: Boston, USA, 2010.

25. Drummond MF, Schulper MJ, Claxton K, Stoddart GL, Torrance GW Methods for the economic evaluation of health care programmes, 4th edn Oxford University Press: Oxford, UK, 2015.

26. Neumann PJ, Ganiats TG, Russell LB, Sanders GD, Siegel JE (eds). Cost-effectiveness in health and medicine, 2nd edn Oxford University Press: New York, USA, 2016.

27. Briggs A, Schulper M, Claxton K Decision modelling for health economic evaluation, Oxford University Press: Oxford, UK, 2006.

28. Sonnenberg FA, Beck JR. Markov models in medical decision making: a practical guide. Med Decis Mak. 1993;13:322-38. https://doi.org/10.1177/0272989X9301300409. e-pub ahead of print 1993/10/01

29. Standing Conference on the Relations between the State, the Regions and the Autonomous Provinces of Trento and Bolzano. National agreement on tariffs for inter-regional mobility of patients. Version in force for 2014-5 and 2016. Rome, 2 February 2017 (in Italian). In.

30. Ministero della Salute. Ministry of Health. Decree 18 October 2012. Tariffs for acute hospitalization, rehabilitation and postacute residential hospitalization. Gazzetta Ufficiale, Serie Generale, n. 23, 28 January 2013. Annex 3. Outpatient health care services (in Italian). In.

31. Ministero della Salute. Ministry of Health. Annual report on hospitalizations. Data obtained from hospital discharge forms 2017. Rome, January 2019 (in Italian). In.

32. Brouwer W, Rutten F, Koopmanschap M Costing in economic evaluations. In: Drummond M, McGuire A (eds). Economic evaluation in health care: merging theory with practice. Oxford University Press: Oxford, UK, 2001, pp 68-93.

33. Fattore G, Torbica A, Mangone M. Cost analysis of four therapeutic strategies for managing mild and severe COPD patients: an application of the bootstrap method (in Italian). Pharmacoeconomics. 2005;7:135-43.

34. Lazzaro C, Ruffo P, Gozzo M. Cost-effectiveness analysis of budesonide/formoterol as maintenance and reliever therapy in the management of asthma. Italian evaluation (in Italian). Pharmacoeconomics. 2009;11:39-53.

35. Lazzaro C, Barone C, Caprioni F, Cascinu S, Falcone A, Maiello E, et al. An Italian cost-effectiveness analysis of paclitaxel albumin (nab-paclitaxel) + gemcitabine vs gemcitabine alone for metastatic pancreatic cancer patients: the APICE study. Expert Rev Pharmacoecon Outcomes Res. 2018;18:435-46. https://doi. org/10.1080/14737167.2018.1464394. e-pub ahead of print 2018/ $04 / 12$

36. Torrinomedica S.r.l. Ricerca Farmaci [database on the Internet]. Rome: Torrinomedica S.r.l. (in Italian). In, 2019.

37. Agenzia delle Entrate. Italian Revenue Agency. National tariffs per kilometer for cars and motorbikes set by the Auto club of Italy - Art. 3, paragraph 1, of the legislative decree 2 September 1997, n. 314. Gazzetta Ufficiale, Serie Generale, n. 295, 20 December 2018, ordinary supplement n. 57: 9 (in Italian). In.

38. Comune di Milano. Municipality of Milan. Authorized parking for non-residents' car (in Italian). In, 2019.

39. Banca d'Italia. Bank of Italy. Survey on Household Income and Wealth 2016: Table 13 (in Italian). In.

40. Istituto Nazionale per la Previdenza Sociale. National Institute for Social Security. Channel Information. Minima daily wages (in Italian). In.

41. Posnett J, Jan S. Indirect cost in economic evaluation: the opportunity cost of unpaid inputs. Health Econ. 1996;5:13-23. epub ahead of print 1996/01/01; 10.1002/(SICI)1099-1050 (199601)5:1<13::AID-HEC182>3.0.CO;2-J.

42. Sculpher $M$ The role and estimation of productivity costs in economic evaluations. In: Drummond M, McGuire A (eds). Economic evaluation in health care: merging theory with practice. Oxford University Press: Oxford, UK, 2001, pp 94-112.

43. Sistema Statistico Nazionale - Istituto Nazionale di Statistica. National Institute for Statistics. Consumer prices index for the whole nation (reference year $2015=100$ ) - monthly data (in Italian). In.

44. Fattore G. for the Italian Association of Health Economics working group. Proposed guide-lines for the economic evaluation of health care programmes in Italy (in Italian). Pharmacoeconomics. 2009;11:83-93.

45. Ministero della Salute. Ministry of Health. Decree 8 February 2013. Criteria for the composition and proper functioning of ethical committees (13A03474). Gazzetta Ufficiale della Repubblica Italiana, Serie Generale, n. 96, 24 April 2013 (in Italian). In.

46. Briggs $\mathrm{AH}$ Handling uncertainty in economic evaluation and presenting the results. In: Drummond M, McGuire A (eds). Economic evaluation in health care: merging theory with practice. Oxford University Press: Oxford, UK, 2001, pp 172-214.

47. Lazzaro C, Lopiano L, Cocito D. Subcutaneous vs intravenous administration of immunoglobulin in chronic inflammatory demyelinating polyneuropathy: an Italian cost-minimization analysis. Neurol Sci. 2014;35:1023-34. https://doi.org/10.1007/ s10072-014-1632-9. e-pub ahead of print 2014/01/29

48. Pagano M, Gauvreau K Principles of biostatistics, 2nd edn Duxbury Press: Pacific Grove, USA, 2000.

49. Briggs AH, Gray AM. Handling uncertainty when performing economic evaluation of healthcare interventions. Health Technol Assess. 1999;3:1-134. e-pub ahead of print 1999/08/17

50. Black WC. The CE plane: a graphic representation of costeffectiveness. Med Decis Mak. 1990;10:212-4. https://doi.org/10. 1177/0272989X9001000308. e-pub ahead of print 1990/07/01

51. Fenwick E, Claxton K, Sculpher M. Representing uncertainty: the role of cost-effectiveness acceptability curves. Health Econ. 2001;10:779-87. https://doi.org/10.1002/hec.635. e-pub ahead of print 2001/12/18

52. Glick HA, Doshi JA, Sonnad SA, Polsky D (eds). Economic evaluation in clinical trials. Oxford University Press: Oxford, UK, 2015.

53. Lanza F, Campioni DC, Hellmann A, Milone G, Wahlin A, Walewski J, et al. Individual quality assessment of autografting by probability estimation for clinical endpoints: a prospective validation study from the European group for blood and marrow transplantation. Biol Blood Marrow Transpl. 2013;19:1670-6. https://doi.org/10.1016/j.bbmt.2013.08.005. e-pub ahead of print 2013/08/31 
54. Pierelli L, Berto P, Accorsi P, Milone G, Lopatriello S, Aiello A, et al. The costs of mobilisation and collection of peripheral blood stem cells in multiple myeloma and lymphoma in an European country: results from The Gruppo Italiano Trapianto Midollo Osseo (GITMO) and Societa Italiana di Emaferesi e Manipolazione Cellulare (SIdEM) survey. Transfus Apher Sci. 2013;49:615-22. https://doi.org/10.1016/j.transci.2013.07.025. epub ahead of print 2013/08/27

55. Laszlo D, Marcacci GP, Martino M, Radice D, Rabascio C, Lucchetti B, et al. A comparison of chemo-free strategy with GCSF plus plerixafor on demand versus intermediate-dose cyclophosphamide and G-CSF as PBSC mobilization in newly diagnosed multiple myeloma patients: An Italian explorative cost Analysis. Transfus Apher Sci. 2020;59:102819 https://doi.org/10. 1016/j.transci.2020.102819. e-pub ahead of print 2020/06/06

56. Shaughnessy P, Chao N, Shapiro J, Walters K, McCarty J, Abhyankar S, et al. Pharmacoeconomics of hematopoietic stem cell mobilization: an overview of current evidence and gaps in the literature. Biol Blood Marrow Transpl. 2013;19:1301-9. https:// doi.org/10.1016/j.bbmt.2013.05.008. e-pub ahead of print 2013/ $05 / 21$

57. Kymes SM, Pusic I, Lambert DL, Gregory M, Carson KR, DiPersio JF. Economic evaluation of plerixafor for stem cell mobilization. Am J Manag Care. 2012;18:33-41. e-pub ahead of print 2012/03/23

58. Tuffaha HW, Hussein AA, Abdel-Rahman FA. Comparative Cost Utility Analysis of Plerixafor Plus GCSF Versus Cyclophosphamide Plus GCSF as Salvage Mobilization Regimens in Multiple Myeloma Patients. Biol Blood Marrow Transpl. 2012;18: S248 https://doi.org/10.1016/j.bbmt.2011.12.132

59. Mark DB, Hlatky MA, Califf RM, Naylor CD, Lee KL, Armstrong PW, et al. Cost effectiveness of thrombolytic therapy with tissue plasminogen activator as compared with streptokinase for acute myocardial infarction. N. Engl J Med. 1995;332:1418-24. https://doi.org/10.1056/NEJM199505253322106. e-pub ahead of print 1995/05/25.

60. Ubel PA, Hirth RA, Chernew ME, Fendrick AM. What is the price of life and why doesn't it increase at the rate of inflation? Arch Intern Med. 2003;163:1637-41. https://doi.org/10.1001/a rchinte.163.14.1637. e-pub ahead of print 2003/07/30

61. National Institute for Health and Care Excellence (NICE). Guide to the methods of technology appraisal 2018. In.

62. Martone N, Lucioni C, Mazzi S, Fadda V. Cost-effectiveness evaluations of new cancer drugs available on the Italian market (in Italian). Glob Reg Health Tech Assess. 2014;1:31-43.

63. Van de Wyngaert Z, Nerich V, Fouquet G, Chretien ML, Caillot $\mathrm{D}$, Azar N, et al. Cost and efficacy of peripheral stem cell mobilization strategies in multiple myeloma. Bone Marrow Transpl. 2020;55:2254-60. https://doi.org/10.1038/s41409-0200940-3. e-pub ahead of print 2020/05/25

64. O'Hagan A, Buck CE, Daneshkhah A, Eiser JR, Garthwaite PH, Jenkinson DJ et al. Uncertain judgements: eliciting experts' probabilities, Wiley: Chichester, UK, 2006.

65. Caro JJ, Briggs AH, Siebert U, Kuntz KM. Modeling good research practices-overview: a report of the ISPOR-SMDM modeling good research practices task force-1. Value Health. 2012;15:796-803. https://doi.org/10.1016/j.jval.2012.06.012. epub ahead of print 2012/09/25

66. Weinstein MC, O’Brien B, Hornberger J, Jackson J, Johannesson $\mathrm{M}$, McCabe C, et al. Principles of good practice for decision analytic modeling in health-care evaluation: report of the ISPOR Task Force on Good Research Practices-modeling studies. Value Health. 2003;6:9-17. https://doi.org/10.1046/j.1524-4733.2003. 00234.x. e-pub ahead of print 2003/01/22 